\title{
"A methodological approach to forecasting spatial distribution of workplaces in an industrial metropolis"
}

\begin{tabular}{|c|c|}
\hline AUTHORS & $\begin{array}{l}\text { Victoria V. Akberdina } \\
\text { Oksana V. Tretyakova } \\
\text { Andrey I. Vlasov }\end{array}$ \\
\hline ARTICLE INFO & $\begin{array}{l}\text { Victoria V. Akberdina, Oksana V. Tretyakova and Andrey I. Vlasov (2017). A } \\
\text { methodological approach to forecasting spatial distribution of workplaces in an } \\
\text { industrial metropolis. Problems and Perspectives in Management, 15(4), 50-61. } \\
\text { doi:10.21511/ppm.15(4).2017.05 }\end{array}$ \\
\hline DOI & http://dx.doi.org/10.21511/ppm.15(4).2017.05 \\
\hline RELEASED ON & Tuesday, 19 December 2017 \\
\hline RECEIVED ON & Wednesday, 25 October 2017 \\
\hline \multirow[t]{2}{*}{ ACCEPTED ON } & Wednesday, 08 November 2017 \\
\hline & \begin{tabular}{|l|}
$(\mathrm{cc}) \overline{\text { EY-NC }}$ \\
\end{tabular} \\
\hline LICENSE & $\begin{array}{l}\text { This work is licensed under a Creative Commons Attribution-NonCommercial } 4.0 \\
\text { International License }\end{array}$ \\
\hline JOURNAL & "Problems and Perspectives in Management" \\
\hline ISSN PRINT & $1727-7051$ \\
\hline ISSN ONLINE & $1810-5467$ \\
\hline PUBLISHER & LLC "Consulting Publishing Company "Business Perspectives" \\
\hline FOUNDER & LLC "Consulting Publishing Company "Business Perspectives" \\
\hline
\end{tabular}

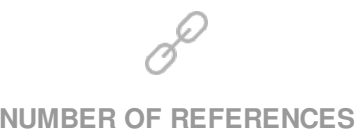

22

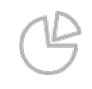

NUMBER OF FIGURES

5

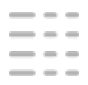

NUMBER OF TABLES

1

(C) The author(s) 2022. This publication is an open access article. 


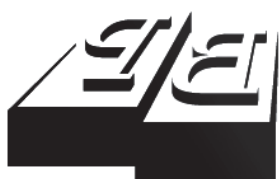

BUSINESS PERSPECTIVES

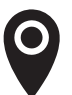

LLC "CPC "Business Perspectives" Hryhorii Skovoroda lane, 10, Sumy, 40022, Ukraine

www.businessperspectives.org

Received on: $25^{\text {th }}$ of October, 2017 Accepted on: $8^{\text {th }}$ of November, 2017

(C) Victoria V. Akberdina, Oksana V. Tretyakova, Andrey I. Vlasov, 2017

Victoria V. Akberdina, Doctor of Economics, Professor of RAS, Institute of Economics of the Ura Branch of the Russian Academy of Sciences, Ural Federal University, Russia.

Oksana V. Tretyakova, Ph.D. (Sociological), Associate Professor, Tyumen Industrial University, Russia.

Andrey I. Vlasov, Ph.D.

(Engineering), Assistant professor, Bauman Moscow State Technical University, Russia.

\section{(ㄷ)(1) $(8)$}

This is an Open Access article, distributed under the terms of the Creative Commons Attribution-NonCommercial 4.0 International license, which permits re-use, distribution, and reproduction, provided the materials aren't used for commercial purposes and the original work is properly cited.
Victoria V. Akberdina (Russia), Oksana V. Tretyakova (Russia),

Andrey I. Vlasov (Russia)

A METHODOLOGICAL APPROACH TO FORECASTING SPATIAL DISTRIBUTION OF WORKPLACES IN AN INDUSTRIAL METROPOLIS

\begin{abstract}
Many world cities retain their unique industrial status. Such a feature of the economy of an industrial metropolis imposes additional requirements on the development of the forecast of spatial distribution of workplaces. The article highlights the contradictions of the long-term development of an industrial megalopolis, which become scenic forks, when forecasted. These include optimization of the industrial and trade-service sectors of the economy, the ratio of inertial and innovative development vectors, variability of migration flows and the choice of the agglomeration model type. The article is devoted to the problem of forecasting the development of a large metropolis, where the industrial sector plays a significant role in the economy. At the methodological level, the article justifies principles of spatial development of an industrial metropolis. The article describes forecasting tools for spatial location of workplaces, based on a combination of several models. The study was performed through the example of Ekaterinburg - the industrial capital of Russia; the metropolis scenarios were justified until 2035; the forecast of spatial distribution was calculated through the example of the two sectors competing for investments - industrial and trade-service. The authors substantiate spatial distribution of workplaces taking into account the projected number of people employed, the number of population of working age and distinguishing features of transport behavior of citizens. The paper demonstrates that the number of large industrial enterprises in a historically industrial center and its first zone decreases, and the modern industry in the form of small and medium-sized businesses located in industrial parks commence gradually forming a circuit with nodes on transport routes towards the largest consumer territories.
\end{abstract}

Keywords

JEL Classification spatial development, city economy, spatial distribution of workplaces, industrial metropolis

C53, E27

\section{INTRODUCTION}

An industrial metropolis is a city with population over one million, in which the share of industry in turnover of organizations exceeds $40 \%$ and the number of people employed in the industrial sphere amounts to approximately $20 \%$ of all economically active inhabitants. The future of any industrial city with a million-strong population in the horizon of 5-10 years is predetermined by the ideas of formation of a comfortable ergonomic space. It aims to create a quality urban environment that is not inferior to the highest global standards. In fact, we are talking about the design of a "post-industrial city" with advanced economy, service infrastructure, modern commerce, entertainment and public leisure. On a broader planning horizon of 10-20 years, the result of this in fact "catching-up" city development is rather predictable and as a matter of principle realistic. However, this result would lack the core value, which only makes a difference in the long-term 
geo-cultural competition of cities for people and projects.

The main objective of the long-term development of an industrial metropolis is to create a future uniqueness of the city. The struggle for uniqueness and diversity of the city is the same investment in its prosperity, as the struggle to attract a "strategic investor", technology parks and clusters. Any industrial city in its long-term development will face four major contradictions. In the horizon of strategic forecasting, one can single out a set of contradictions that allow structuring the scenario choice, identifying possible strategies for the city and justify the objectives of its development under the new conditions.

First, the key contradiction in the development of a historically industrial city is the contradiction in the structure of the city economy (Gugler, 2004; Taşan-Kok \& Baeten, 2011). The sphere of production enters into a contradiction with the sphere of distribution, while the financial sector and the social sector act as service industries.

Secondly, the contradiction of any development is the contradiction of "inertia-innovation" (Anheier \& Fliegauf, 2013; Silverstein et al., 2007). The choice lies in the preferences and features of the city development tools. The inertial motion involves gradual copying of solutions and their gradual implementation in the market logic. The innovative option involves anticipating project development of the city through advanced standards and technologies. However, accelerated investment growth cannot continue indefinitely - in the end, it comes into conflict with the infrastructure limitations (energy, capacity transport paths, etc.) and the decreasing efficiency of transaction load (Dubrovsky et al., 2016). Then this type of growth is replaced by innovative growth associated with the search for new technologies, while the quality of such development significantly changes.

Thirdly, within the framework of a long-term forecast, there is always a contradiction in the labor force (Fernandez-Macias et al., 2012; Zhang, 2011; Carmona, 2002). The resident population of the city, subject to objective demographic trends, cannot constantly provide the supply of labor sufficient to ensure the growth of the city economy.

Fourth, the development of agglomerations, being an inevitable process, will cause a contradiction associated with the agglomeration development model (Gordon \& McCann, 2005; Wallsten, 2004). The choice of the development and management model of the agglomeration will make appropriate demands for the spatial development of metropolis and its suburbs, the interface between the sectoral and territorial structure of the agglomeration and formation of the infrastructure development options.

The above contradictions are the main scenic forks of the long-term development of any industrial metropolis. The choice of an optimal approach is preceded by development and implementation of a single methodological platform and forecasting tools for conducting multidimensional spatial analysis and modeling aimed at the urban environmental planning.

The purpose of this study is to validate the choice of approaches and models to forecast the long-term spatial development of the city, where the industrial sector plays a significant role in economy. The approaches described in the methodological part of the article have been implemented in the project of perspective development of the micro-districts of Ekaterinburg, which is, historically, the industrial capital of Russia. The objectives of the project included the following:

1) the current assessment of the economic efficiency of the metropolitan area;

2) justification of scenic forks in the forecasting interval up to 2035;

3) forecast of the metropolis workplace location in the context of economic activities. 


\section{MATERIALS AND METHODS}

The basis of modeling is the idea of the city as a system of territory elements, each of which can be characterized by the type and activity of use and functional connectivity with other elements of the territory. According to the most popular gravity model, the correspondence between any two territorial elements (neighborhoods) increases in direct proportion to their conditional "weight" (indication of the intensity of use) and is reversely proportional to the distance between them (Ke et al., 2017). For example, the number of workplaces within a certain micro-district determines its "generating" capacity, whereas the employment of its population defines its "absorbing" capacity.

The algorithm for socio-economic monitoring of workplaces is based on a wide array of data on the megalopolis enterprises. The algorithm for socioeconomic monitoring of workplaces developed by the authors encompasses the assessment of the socio-economic situation and the assessment of availability of infrastructure of the major workplaces. The best way to obtain the actual data is to use specialized databases that provide information on the number and financial indicators with reference to the actual location of objects. The analysis of projects is carried out in the mode of monitoring regional strategic documents, programs, lists of enterprises that received support measures for implementation of projects, as well as information inquiries to local administrations, branch unions, small business associations, entrepreneurs support funds, requests to profile ministries, employment centers, etc.

Based on these data, the analysis of workplace location in the context of metropolitan districts is carried out, along with the analysis of projects (plans) of enterprises and organizations (in the context of the most important economic activities - industry, trade and services, social affairs, finance, transport, communications, public sector and others). The disclosure of analytical information is carried out both in general by the type of activity, and in the context of the size of enterprises.

The development of a long-term concept for development of the residential micro-districts is based on the following methodological platform.
1. The first group of models is based on the use of statistical reports on population resettlement, places of employment and population movements for the past period. This includes the single growth rate method, average growth factors, the Detroit method and the Fratar method (Trip Distribution Techniques, n.d.). These approaches allow forecasting the demand for movement considering the nature of change in the passenger traffic between transport areas in the future.

2. The second group of models includes models that simulate the aggregate demand for "labor" and "social" movements based on gravitational and entropic approaches. Among the approaches of this group, particular attention should be paid to Stoffer's "method of possibilities" (Ortuzar \& Willmsen, 2006), according to which the process of population movement is accepted as probabilistic.

3. The third group of models are discrete choice models (Evenett \& Keller, 2002), which allow describing the process of resettlement and "labor" and "social" displacement as a function with complex parameters.

4. The fourth group of models is evaluative and is based on calculations of integral estimates of territorial capital, structural-functional and socio-demographic potential of micro-districts.

There are three principal aspects of the concept development. First, it is ensuring polycentric development of an industrial metropolis. The competitiveness of an industrial metropolis is directly related to its ability to perform specific functions of the metropolitan territory. Historical experience shows that cities that deliberately pursue "metropolization" policy generally significantly increase their place in the urban hierarchy. Several studies note possible negative consequences of over-concentration of population and resources in large urban areas (environmental risks and recovery costs; an increase in the alternative cost of new projects in megacities (Scimemi \& Teodori, 1964; and others). To reduce such negative trends, it is necessary to adhere to the important principle of a spatial strategy, namely the principle of polycentricity (Biyakov, 2004). 
In this regard, the results of the developed concept will ensure simultaneous compliance with the principle of polycentricity and the principle of investment efficiency. The principle of polycentricity is directly related to the identification and maintenance of specialization of the metropolitan areas that will form the framework of the urban settlement, representing a hierarchically constructed set of micro-districts of different level and specializations, according to cyclical tendencies. This will allow speaking of the "wireframe effect" (Lappo et al., 2007), which is understood as a set of positive results of economic and social interaction of the micro-districts in order to ensure the competitiveness of the city as a whole.

Secondly, it is creation of a comfortable environment and ensuring the quality of life. The second aspect is the concept of a modern comfortable city, which assumes an equal access to the city's infrastructure and the benefits of engineering improvement. Micro-districts are designed for multifunctional provision of residents within a walking distance to: shops, parks, libraries, entertainment facilities, police departments, etc., which enables residents to live in comfortable surroundings without using transport and long distance driving (Matafonov et al., 2003). Such decisions will prevent the city from "sprawling" beyond its borders, and will create new planning units of low-density individual development on the outskirts of the city with multifunctional service areas and workplaces.

Thirdly, it is ensuring the effective use of territorial capital. The defining moment in the rate of economic growth of a metropolis micro-district is the quantity and quality of territorial capital. The concept of territorial capital implies that the same investments in different micro-districts will lead to different results, both at the district level and at the city level (Romão \& Neuts, 2017). The competitiveness achieved due to the features of the microdistrict, the efficiency of infrastructure and services, benefits the entire economy of the city (Greene et al., 2017).

Thus, the consideration of these aspects will allow offering a decision support system for the microdistricts and the city as a whole, making it possible to analyze and visualize critical spatial patterns, forming the territorial capital.

\section{RESULTS}

The algorithm for the socio-economic monitoring of workplaces includes an assessment of infrastructure availability for the main workplaces. The assessment includes the following infrastructure elements: transport and logistics (warehouses, places of temporary storage of cars, public transport stops, etc.), engineering (necessary communications, networks), information and communication (Internet access points, contact points, etc.), financial (banks, cash settlement centers, etc.), business (notary, lawyer's offices, etc.), engineering and security infrastructure (video surveillance in the streets, access control, etc.). As for criteria for assessing the availability of the above-mentioned objects, the authors propose to use a set of standards approved in the city and region, along with (in the absence of an appropriate standard of security) the national and world standards. At the same time, the main attention is paid to the density characteristics of the specified urban functions. The spatial analysis of the city determines the distribution of the most important density characteristics that reveal the intensity of development of each single micro-district.

The methods of analysis of the socio-economic situation in the workplaces are rather complex and consist of the two main units: Unit 1 - Analysis of the socio-economic situation in the workplaces based on statistical data; Unit 2 - Analysis of the socio-economic situation in the workplaces based on a sociological survey.

\section{Unit 1.}

The major structural components of the analysis are the following (the analysis is carried out for the most important types of economic activity industry, trade and services, social sphere, financial sphere, transport, communications, public sector):

1. The level of economic activity localization (including the number of enterprises of the $i$-th industry group on the whole territory of the micro-district, the number of enterprises of all industry groups throughout the micro-district). The key indicators are: 


$$
K_{\text {empl }}=\frac{V_{\text {empl }}^{\text {microdistrict }}}{V_{\text {empl }}^{\text {city }}} \cdot 100,
$$

where $K_{e m p l}$ - the share of the micro-district in the number of persons employed, \%; $V^{\text {micro-district }}-$ the number of employees in the micro-district; $V_{\text {empl }}^{\text {city }}-$ the number of employees in the city.

$$
K_{c o m}=\frac{V_{c o m}^{\text {micro-district }}}{V_{c o m}^{\text {city }}} \cdot 100,
$$

where $K_{c o m}$ - the share of the micro-district in the number of enterprises, $\% ; V^{\text {micro-district }}$ - the number of enterprises in the micro-district; $V_{c o m}^{\text {city }}$ - total number of enterprises in the city.

$$
K_{\text {empl }}^{\prime}=\frac{V_{\text {empl }}^{,_{\text {micro-district }}}}{V_{\text {empl }}^{\text {cily }^{\text {city }}}} \cdot 100,
$$

where $K_{\text {empl }}^{\prime}$ - the share of the micro-district in the number of persons employed at the enterprises of a certain scale, $\%$; $V^{\text {micro-district }}-$ the number of employees of the enterprises of a certain scale in the micro-district; $V_{\text {empl }}^{\text {city }}$ - total number of employees of the enterprises of a certain scale in the city.

$$
K_{\text {com }}^{\prime}=\frac{V_{\text {com }}^{1_{\text {micro-district }}^{\text {cily }}}}{V_{\text {com }}^{\text {com }^{\prime}}} \cdot 100,
$$

where $K_{\text {com }}^{\prime}$ - the share of the micro-district in the number of enterprises of a certain scale, \%; $V^{\text {micro-district }}-$ the number of enterprises of a certain scale in the micro-district; $V^{{ }^{\text {city }}}$ - total number of enterprises of a certain scale in the city.

$$
K_{\text {EconActiv }}=\frac{V_{\text {EconActiv }}^{\text {micro-district }}}{V_{\text {EconActiv }}^{\text {city }}} \times 100 \text {, }
$$

where $K_{\text {EconActiv }}$ - the share of the micro-district in the number of persons employed at the enterprises in the defined foreign economic activity, \%; $V_{\text {Econdectiv }}^{\text {microdistict }}$ - the number of organizations in the defined foreign economic activity in the micro-district; $V_{\text {Econtcivi }}^{\text {city }}$ - total number of organizations in the defined foreign economic activity in the city.

The density of economic activity (including the density of the integrated use of the district territory; density of the micro-district territory use for economic activity by integrated groups, the diversity of economic activity) - density values can be determined per unit area, it is also possible to estimate the indicators per one person employed. The key indicators are:

$$
F_{1}=\frac{D_{e m p l}}{M} \cdot 100
$$

where $F_{1}$ - the density of economic activity in the micro-district, persons per 1 sq.km; $D_{e m p l}-$ the number of employed in the micro-district; $M$ the micro-district territory.

$$
F_{2}=\frac{D_{c o m}}{M} \cdot 100,
$$

where $F_{2}$ - the turnover of enterprises in the micro-district, thousand rub./1 sq.km; $D_{\text {com }}$ - the turnover of enterprises in the micro-district; $M$ - the micro-district territory.

2. Localization of economic efficiency of the territory (assessment of the results of economic activity of economic entities located in the territory of micro-districts, for example, the share of loss-making enterprises in the total number of economic entities located in the micro-district, the profitability of the micro-district enterprises, etc.). The key indicators: the average salary in the micro-district; the average labor productivity in the micro-district, the average index of due diligence of organizations in the micro-district (credit risks and scoring ratings).

3. Transport accessibility of workplaces (including significance coefficients of parking lots, significance of the distance to the city center, scale coefficients of the micro-district location within the territory of the city). The distance units (kilometers) are the key measurement units, characterizing transport accessibility, their use allows not only calculating the average distance between the objects, but also assessing their availability. The key indicators: the average distance from a certain micro-district to all others, the average time and cost of traveling by car from a certain micro-district to all others, the average time and cost of travel by public transport (with a minimum number of transplants) from a certain micro-district to all others.

\section{Unit 2.}

Analysis of the socio-economic situation in the workplaces based on a sociological survey. The results of the sociological survey and the analysis of the re- 


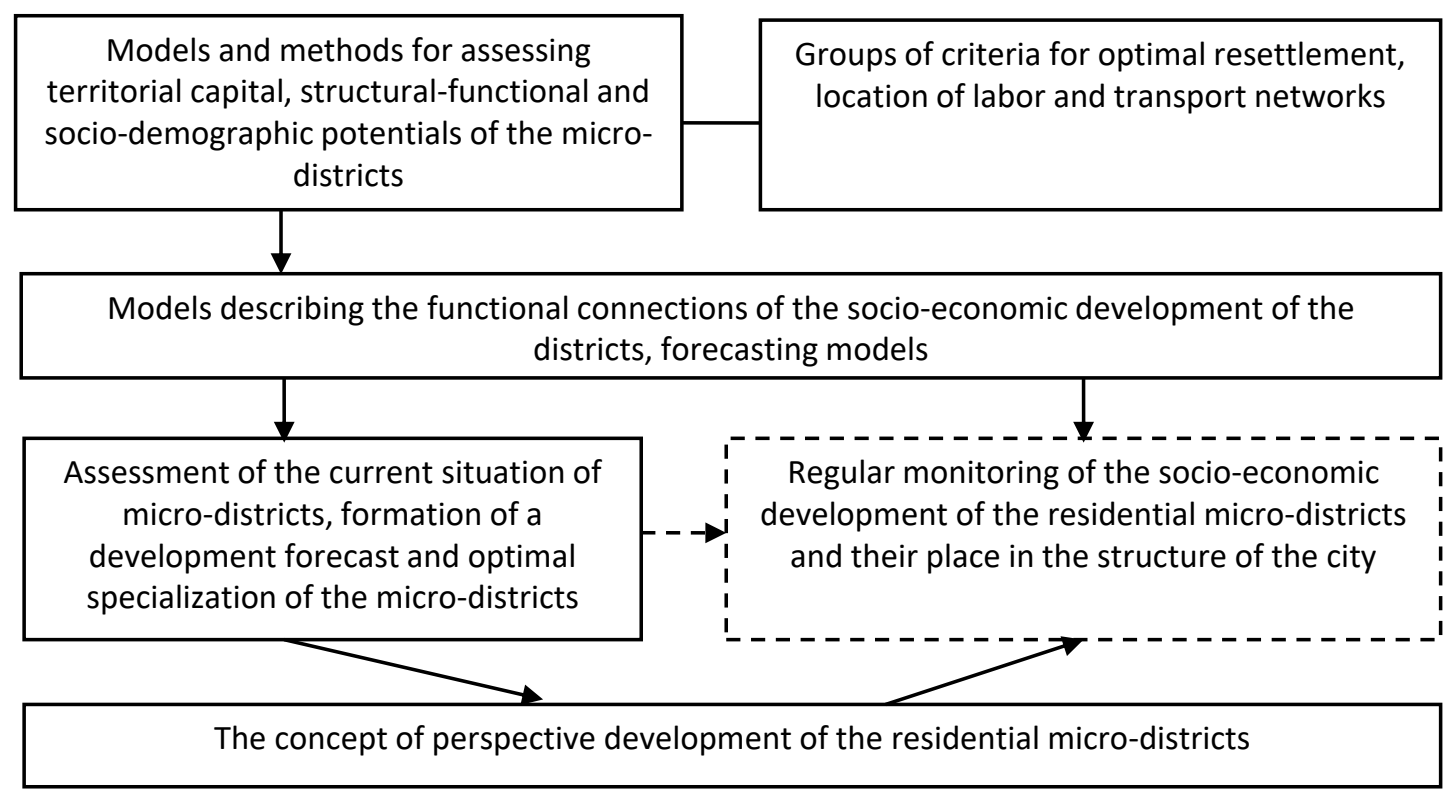

Figure 1. The scheme of the methods for shaping the concept of perspective development of the residential micro-districts of the metropolis

sults obtained will allow characterizing the attitude of the population to the workplace localization. The purpose of the analysis is to reveal the structural concreteness of the city space in its current state, to formulate the perspective problems of urbanization, which are necessary for understanding the economic fate and competitiveness of the micro-districts.

The following statistical procedures are used for the analysis:

1) descriptive statistics;

2) reliability statistics (estimation of confidence intervals, testing of hypotheses);

3) analysis of contingency, correlation analysis (calculation and verification of the significance of Kendall, Spearman, Cramer and Pearson coefficients);

4) tests for independent samples (to compare different groups of respondents): ANOVA variance analysis to estimate the differences between the averages; Leuven's test for estimating the homogeneity of the compared groups; The Shapiro - Wilks test for estimating the normality of the distribution of quantitative variables; Nonparametric tests (KruskalWallis test and median test).
Figure 1 shows the scheme of the methods for shaping the concept of perspective development of residential micro-districts of the metropolis.

The method for creating the concept of perspective development of residential micro-districts of an industrial megacity consists of:

a. a set of models and methods for assessing territorial capital, structural and functional and socio-demographic potentials of micro-districts (statistical and survey methods);

b. a group of criteria for the optimality of resettlement, location of the workplaces and transport networks (urban planning standards);

c. a set of models that characterize functional links between the indicators of socio-economic development of micro-districts, and forecast models (a system of balanced indicators of micro-districts, of which rating is the integral indicator);

d. the algorithm of actions for assessing the current situation of micro-districts, formation of a development forecast and the optimal specialization of micro-districts;

e. methods and algorithm for monitoring the long-term socio-economic development of the 
residential micro-districts and their place in the structure of a metropolis;

f. the structure of the concept of micro-districts with the characteristic of the basic sections and formats of results visualization.

Our approach allows obtaining a systematic and coordinated forecast of the long-term spatial development for an industrial metropolis.

\section{DISCUSSION}

Russia is an industrialized country rich in gas, oil and other mineral resources. This abundance helped the nation to take a lead among other economies that are virtually $100 \%$ dependent on the extracted fuel. Russian industrial cities form the basis of the economic development of the state. In the territory of Russia, there are about 300 such centers situated in the Far East, the Urals and the northern part of the Caucasus. Some of them are located in central Russia. Among the Russian cities with a population above one million people, Ekaterinburg has a leading position after Moscow and St. Petersburg. According to Rosstat, Ekaterinburg has a combined rating of 1 . Such a high rating is due, first of all, to high wages, development of trade, services and housing construction. The analysis of Eurostat data made it possible to single out European cities with a population above one million people with the same structure of the city economy as in Ekaterinburg. Currently, the share of the city's population working in industry is $19.4 \%$. The closest values for this indicator are the following industrialized European cities with a population above one million people: Greater Milan (19.3\%), Greater Naples (15.7\%), Lyon (11.9\%), Munich (11.3\%), Greater Manchester (10.7\%), Budapest (10.7\%), Hamburg (10.3\%) and Cologne (10.2\%).

Since 2000, the ratio of the volume of turnover for the trade-service sector (retail trade, public catering, paid services to the population, household services) to the industrial sector of Ekaterinburg's economy is constantly increasing. The given indicator characterizes the structure of the city's economy and is dependent on numerous factors, such as historical specialization, availability of resources, economic efficiency of the leading sectors and distinctive features of their innovation development. The ratio of the leading sectors shows how many rubles created in the sphere of trade and services correspond to one ruble generated in industry.

Despite the inevitable rapid development of the tertiary sector (trade, services, maintenance, public catering), the city's industrial sector has considerable potential for innovation. The reason is that the nucleus of city industrial sector consists of enterprises of the defense-industrial complex, characterized by high-tech manufactures of the new technological structures. Over the past 15 years, Ekaterinburg shows a relatively high investment growth rate, much higher than the corresponding figures for other Russian cities with a population above one million people.

The scenic territory of the city development is due to a number of contradictions. After all, when creating scenarios for the development of Ekaterinburg, we used three scripted forks, each fork resulted in two alternative scenarios. We believe it is possible to identify typical scenarios for development of an industrial metropolis:

a. scenario within the industrial vector (innovative);

b. preservation of the existing trend of uncontrolled growth in the trade sector is fully visible in the inertial scenario, which could lead to a complete de-industrialization of the city and the loss of the status of the "industrial capital of the region";

c. and finally, the baseline scenario will be implemented as part of the trade vector, though with preservation of the industrial component of the city economy.

The main fork of the scenarios - structural fork defines two vectors of development: industrial and trade-service. To carry out predictive calculations, one scenario has been selected as part of the industrial vector and two other scenarios - as part of the trade-service vector (Lavrikova et al., 2017).

Forecasting will be carried out considering the socio-economic development of the city until 2035, 


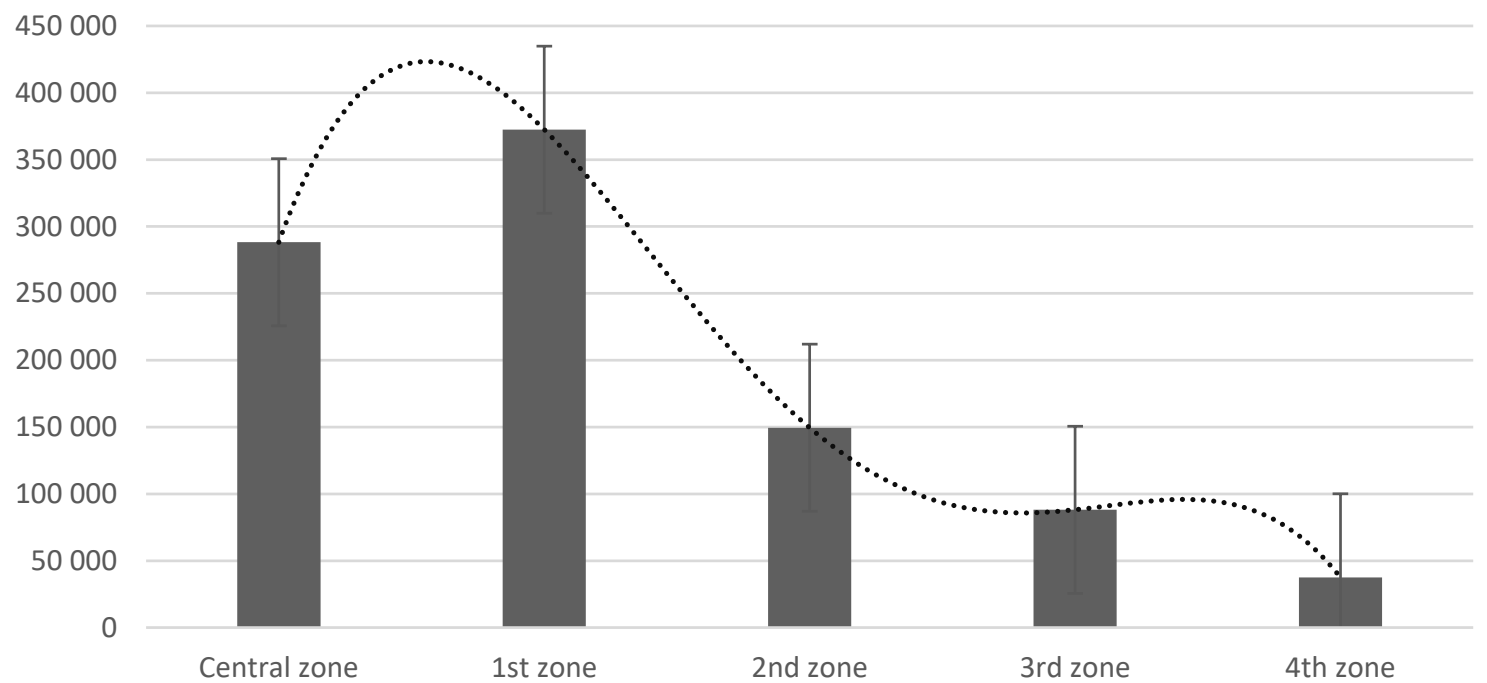

Figure 2. The number of employed in the Ekaterinburg city economy in terms of spatial zones, 2015

providing implementation of several scenarios, including the new industrialization scenario and the prevailing scenario of the trade-service sector. For the forecast of the economic structure of the city both in terms of turnover and in numbers, it is the starting point for predicting economic indicators. The influence of structural changes is evident in the dynamics.

The territory of Ekaterinburg consists of 66 microdistricts of different scale and different specialization. The main problem of the majority of microdistricts of any industrial megacity, including Ekaterinburg, is the lack of diversification, which is a serious limitation of long-term development. Concerning the localization of industry in terms of the occupied territory, it is necessary to note the following. The industrial areas of Ekaterinburg are vast and varied. Today, they occupy about $30 \%$ of the total territory of the city. Depending on specialization, the industrial enterprises of Ekaterinburg relate to heavy engineering and machine-tool construction, metallurgy, production of metal products, production of building materials, production of rubber and plastic products, chemical industry and food industry.

In Ekaterinburg, the largest micro-district in terms of the workplaces localization is the Central Micro-district. Around $30.8 \%$ of the total number of people employed in Ekaterinburg refer to its territory. The next five of the most important workplace locations with a $5-8 \%$ share in the popula- tion are the micro-districts of the first zone. In total, $79.8 \%$ of all the employed in Ekaterinburg work in the Central zone and 10 other largest micro-districts. At present, $70.6 \%$ of the employed in the city's economy work in the Central (30.8\%) and the first zone from the center $-39.8 \%$ (Figure 2).

According to our estimates, by the year 2035, the growth rate of the total number of employed in Ekaterinburg will be $106.7 \%$ compared to the level of 2015 in case of the innovation scenario. At the same time, there will be changes in the structure of the workplace localization. Thus, the number of employed in the Central zone will significantly decrease (by 11.8\%), and the share of employees in the Central zone will decrease from $30.8 \%$ to $25.4 \%$. If in 2015 almost every third employee worked in the Center, by the year 2035 every fourth citizen will work there (Figure 3).

In 2035, the growth rate of the number of employed in the first zone will make $109.2 \%$ compared to the level of 2015, and the share of workers there will increase from $29.8 \%$ to $40.7 \%$. In terms of the number of employees, the first zone will remain the largest. The second zone will show quite a dynamic development. The growth in the number of employed in 2035 will be $23.4 \%$ compared to the level of 2015, and their share will increase from $16 \%$ to $18.5 \%$.

The key industries of the Ekaterinburg city are the industrial sector (mining, processing and power gen- 


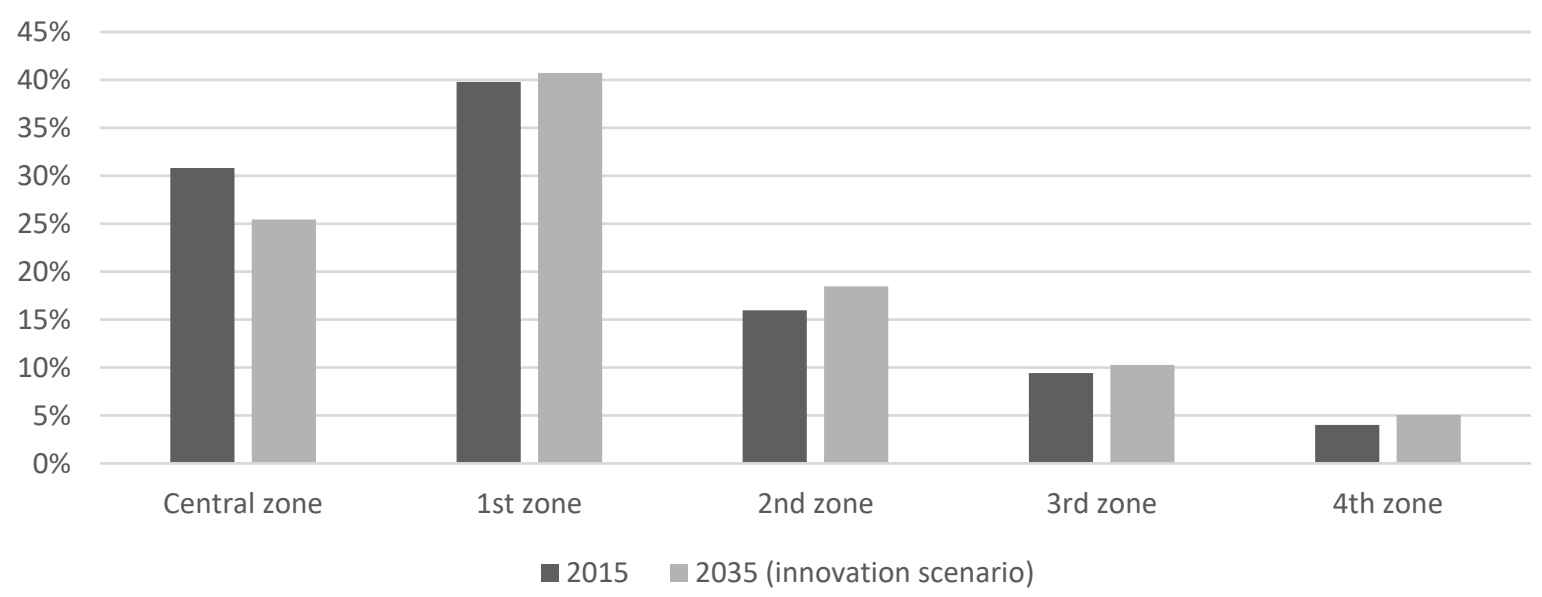

Figure 3. The structure of population in the context of spatial zones, 2015 and 2035

eration) and the trade-service sector (trade, catering, hotels and service industry). The structure of the number of enterprises and organizations of the city under the inertial scenario will change significantly. According to estimates, by 2035, in case of the innovative scenario, the share of employed in the industrial sector will be $18 \%$, which will be more closely connected with technological changes that objectively envisage automation of industrial production; the share of the trade-service sector will amount to $21 \%$ (see Table 1). At the same time, in each microdistrict the proportion of those employed in the key sectors of economy will differ significantly.

Thus, in the Center in 2015, the share of employed in the industrial sector was $9.5 \%$, while the tradeservice sector amounted only to $13.5 \%$. The main share of employed was in the public, financial and social sectors. By 2035, the share of employed in the industrial sector in the Center will be reduced to $5 \%$, and the share of the trade-service sector will increase by two times.
The analysis of the city's micro-districts shows that they have their own specifics. This can be seen through the example of the Central microdistrict. The main types of economic activity are state administration (14.5\%), transport organizations $(12.4 \%)$, trade $(10 \%)$, financial services $(10 \%)$, industry (9.5\%), health (8.5\%), energy (8.2\%) and education (8.1\%).

The loss of the industrial status of the city is clearly visible in the inertial scenario. By the end of 2035, the share of the industrial sector will not exceed $30 \%$, while the share of the trade-service sector will account for half of the turnover of the city's organizations (Figure 4). The innovation scenario will allow speaking of parity of the two most important sectors for the city economy - their share will amount to $40 \%$, which will allow using the potential of the trade-service sector for investment development of the real sector of economy. The basic variant assumes an intermediate variant of the turnover structure.

Table 1. Forecast of the structure of employed in terms of the key sectors of the Ekaterinburg economy

\begin{tabular}{|c|c|c|c|c|c|c|}
\hline \multirow{3}{*}{ Zone/Micro-district } & \multicolumn{6}{|c|}{ Structural changes } \\
\hline & \multicolumn{3}{|c|}{2015} & \multicolumn{3}{|c|}{2035} \\
\hline & $\begin{array}{l}\text { Industrial } \\
\text { sector, \% }\end{array}$ & $\begin{array}{c}\text { Trade-service } \\
\text { sector, \% }\end{array}$ & Others, \% & $\begin{array}{l}\text { Industrial } \\
\text { sector, \% }\end{array}$ & $\begin{array}{c}\text { Trade-service } \\
\text { sector, \% }\end{array}$ & Others, \% \\
\hline Ekaterinburg & 20.5 & 15.2 & 64.3 & 18.0 & 21.0 & 61.0 \\
\hline Center & 9.5 & 13.5 & 77.0 & 5.0 & 26.0 & 69.0 \\
\hline 1st zone & 23.9 & 26.3 & 49.8 & 20.3 & 29.4 & 50.3 \\
\hline 2nd zone & 26.1 & 27.3 & 46.6 & 23.1 & 27.9 & 49.0 \\
\hline 3rd zone & 27.2 & 25.6 & 47.2 & 26.5 & 37.4 & 36.1 \\
\hline 4th zone & 27.3 & 19.3 & 53.4 & 24.5 & 21.4 & 54.2 \\
\hline
\end{tabular}




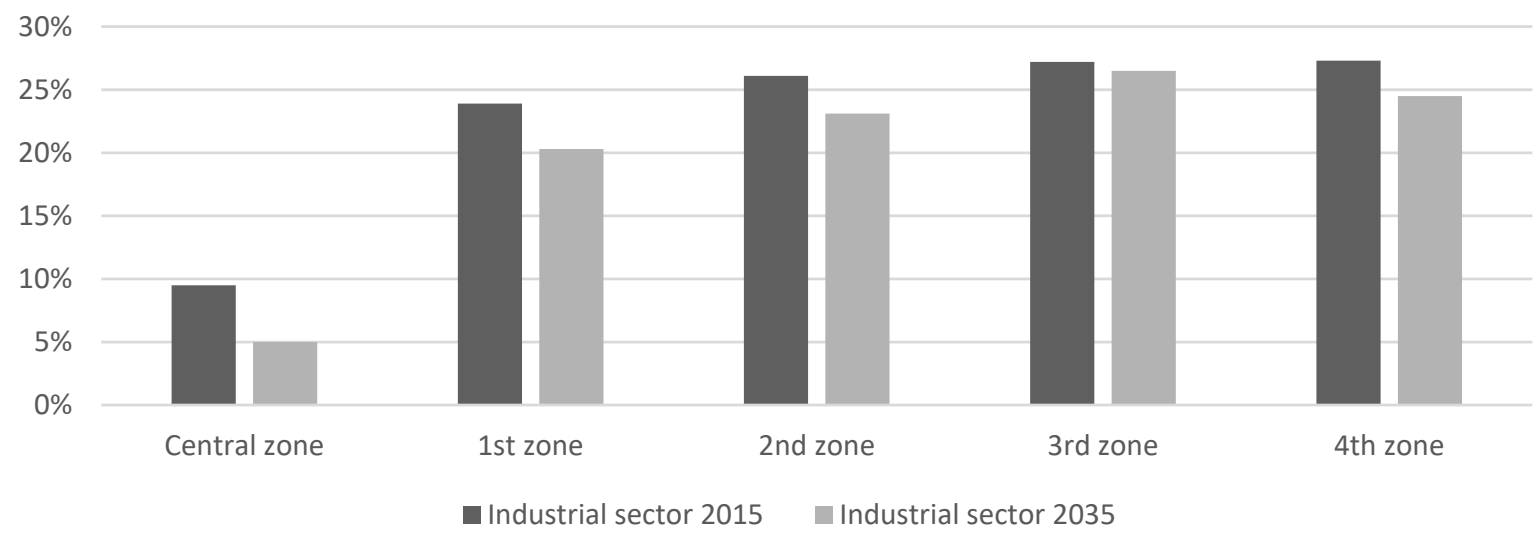

Figure 4. Forecast of the share of the industrial sector in the economic structure of Ekaterinburg micro-districts

The share of employed in the industrial sector in the first, second and fourth zones will also significantly decrease. This trend will be less evident in the third zone. The growth in the share of trade in the structure of economy will increase dramatically in the Central and in the third zones (Figure 5).

Therefore, the spatial development of industrial Ekaterinburg will adhere to the following trends.

1. By 2035, the share of employed in the industrial sector will be reduced objectively (up to $18 \%$ of all the employed) with a significant increase (by $40 \%$ ) in labor productivity and the share of the sector in the turnover of enterprises. In the spatial aspect, the industrial sector will shrink significantly in the Center (2 times) and in the first zone micro-districts. A new industry with less need for workers will emerge in the third and fourth zones of the city in the format of medium and small hightech business located in industrial and technical parks. The fourth zone industry will grow due to its satellite towns.

2. In the trade-service sector of economy, the labor productivity is much lower than in the industrial sector; therefore, with a share of $40 \%$ in the turnover of enterprises, the share of the employed will be $25 \%$. In the spatial aspect, a significant growth in the trade-service sector is expected in the central zone (due to displacement of the industrial sector) and in the third zone due to the growth in the settlement density.

3. By 2035 , the transport flows will also be adjusted. The main load on the road transport network will shift from the center to the second and third zones, with the increase of the density of population and workplaces.

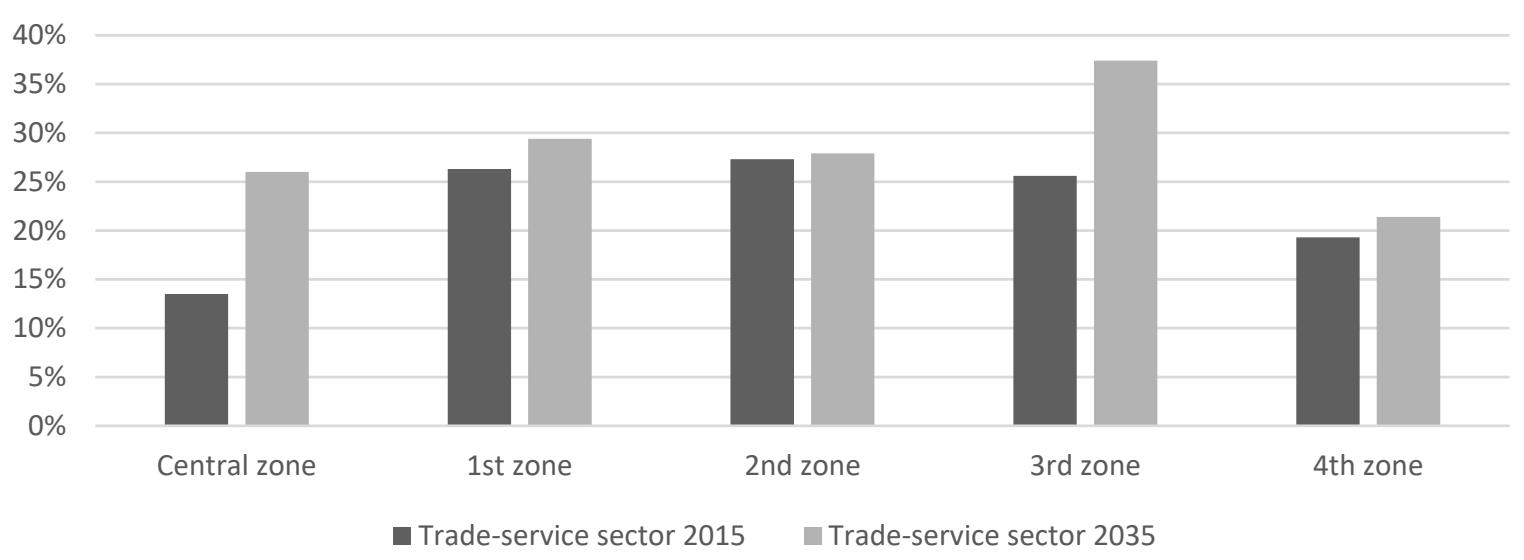

Figure 5. Forecast of the share of trade-service sector in the economic structure of Ekaterinburg micro-districts 


\section{CONCLUSION}

In conclusion, it should be noted that the spatial aspects of the forecast of the workplace location in any metropolis are individual and determined by such factors as: the key industries and their location, the cost of land in the city's districts, the existing construction features, the efficiency of the road network, etc. At the same time, forecasting for a period of 20 years inevitably includes short- and medium-term planning cycles. However, at the stage of setting the task of developing a long-term forecast, considering the tactical and local development priorities of the city, attention should be paid to the methods of strategic urbanism.

The methods discussed in the paper allow substantiating the quantitative forecast of spatial location of workplaces on the basis of population resettlement models, gravitational models of transport behavior of residents and models of economic efficiency of the city space. The rationale behind the presented approach was a method based on calculations of integral estimates of territorial capital, as well as structural-functional and socio-demographic potential of micro-districts of a metropolis. The developed method allows justifying the forecast profile of a micro-district, resolving the problems of particular single-industry micro-districts that encounter development risks, social problems and outward migration flaws.

To demonstrate the implementation of the given method, we addressed the case of the largest industrial metropolis of Russia - the city of Ekaterinburg, which contains 66 micro-districts of different specialization. The industrial sector occupying more than a third of the city's territory was located historically in the center, the first and the second zones during the formation of the city and the period of the first industrialization. At the moment, economic efficiency of industry in the center of the city and its first two zones has decreased significantly giving way to the tertiary sector of economy. The efficiency of investment carried out at enterprises of the first wave of industrialization turns out to be considerably lower than that at enterprises established in the context of new industrialization. Hence, industry is being moved to the third and the fourth zones of the metropolis generating new workplaces there and emerging as centers of development of new micro-districts. Acting simultaneously with the mechanisms of population resettlement and housing construction, new industry forms subcenters of the metropolis development, and thereby implementing the principle of polycentric development of a city with population exceeding one million inhabitants.

Thus, there are quite a number of scenario-dependent variants of the metropolis's development until 2035. However, seriously alternative variants of development might appear in the period 2030-2050, when the current "inevitable" problems will be solved and a question will arise with respect to formation of the new quality of the urban environment for Ekaterinburg as a city at the cognitive phase of development.

\section{ACKNOWLEDGEMENTS}

The study was prepared with financial support from the Russian Foundation for Basic Research (RFBR), in terms of the project "Modeling flows in the entrepreneurial eco-system of the middle subregion", No. 15-06-08375.

\section{REFERENCES}

1. Anheier, H. K., \& Fliegauf, M. T. (2013). The Contribution of Innovation Research to Understanding Governance Innovation: A Review. In H. K. Anheier (Ed.). Governance Challenges and Innovations: Financial and Fiscal Governance (pp. 137-170). OUP Oxford.
2. Biyakov, O. A. (2004). The Theory of Economic Space: Methodological and Regional Aspects. Tomsk: Tomsk University Publ. House (p. 152).

3. Carmona, M. (2002). The Regional Dimension of the Compact
City Debate: Larin America. In R. Burgess, \& M. Jenks (Eds.). Compact Cities: Sustainable Urban Forms for Developing Countries (pp. 53-60) Routledge.

4. Dubrovsky, V., Yaroshevich, N., \& Kuzmin, E. (2016). Transactional 
Approach in Assessment of Operational Performance of Companies in Transport Infrastructure. Journal of Industrial Engineering and Management, 9(2), 389-412. Retrieved from http:// upcommons.upc.edu/bitstream/ handle/2117/88988/1721-8708-1PB.pdf

5. Evenett, S. J., \& Keller, W. (2002). On Theories Explaining the Success of the Gravity Equation. Journal of Political Economy, 110, 281-316.

6. Fernandez-Macias, E., Hurley, J., \& Storrie, D. (Eds.) (2012). Transformation of the Employment Structure in the EU and USA, 1995-2007. Palgrave Macmillan.

7. Gordon, I. R., \& McCann, P. (2005). Clusters, Innovation and Regional Development: An Analysis of Current Theories and Evidence. In Karlsson Ch., Johansson B. \& Stough R. R. (Eds.). Industrial Clusters and Inter-Firm Networks (pp. 29-55). Cheltenham, UK and Northampton, MA: Edward Elgar.

8. Greene, M., Figueroa, C., \& Mora, R. (2017). The Construction of Three Metropolises: A Geographic, Productive and Configurational Process. In Proceedings of the 11th International Space Syntax Symposium, SSS 2017 (pp. 59.1-59.12).

9. Gugler, J. (Ed.). (2004). World Cities Beyond the West: Globalization, Development and Inequality. Cambridge University Press.

10. Ke, W., Chen, W., \& Yu, Z. (2017) Uncovering Spatial Structures of Regional City Networks from Expressway Traffic Flow Data: A Case Study from Jiangsu Province, China. Sustainability, 9(9), 1541. Retrieved from http://www.mdpi. com/2071-1050/9/9/1541

11. Kruskal W. H., Wallis W. A. (1952). Use of ranks in one-criterion variance analysis. Journal of the American Statistical Association, 47(260), 583-621.

12. Lappo, G., Polyan, P., \& Selivanova, T. (2007). Agglomerations in Russia in the 21st Century. Bulletin of the Regional Development Fund of the Irkutsk Region, 1, 45-52. Retrieved from http://iopscience. iop.org/article/10.1088/1755 1315/72/1/012011/pdf

13. Lavrikova, Y., Akberdina, V., \& Mezentseva, E. (2017). Strategic Guidelines of a Megalopolis's Development: New Industrialization and Ecological Tension. IOP Conference Series: Earth and Environmental Science, 72(1).

14. Matafonov, M. E., Verbitskaya, N. O., Fedorov, V. A., \& Kuchinskaya, V. E. (2003). Human Resources of the Largest City: Models, Forecasting, Management (p. 148). Ekaterinburg: Pravoved-2001.

15. Ortuzar, J. de D., \& Willumsen, L. G. (2006). Modelling Transport ( $3^{\text {rd }}$ ed.) (p. 499). John Wiley \& Sons Ltd. Retrieved from https:// www.cabdirect.org/cabdirect/abstract/20173333634

16. Romão, J., \& Neuts, B. (2017). Territorial Capital, Smart Tourism Specialization and Sustainable Regional Development:
Experiences from Europe. Habitat International, 68, 64-74.

17. Scimemi, G., \& Teodori, E. (1964). Population Problems, National Planning and Housing Policies in Italy. Report to the 27th World Congress of Housing, Urbanism and Zoning, Israel. Rome: Istituto di urbanistica della Facoltà di architettura, Università di Roma.

18. Silverstein, D., DeCarlo, N., \& Slocum, M. (2007). Insourcing Innovation: How to Achieve Competitive Excellence Using TRIZ ( $\mathrm{p}$. 23). CRC Press.

19. Taşan-Kok, T., \& Baeten, G. (2011). Contradictions of Neoliberal Planning: Cities, Policies, and Politics. Springer Science \& Business Media.

20. Trip Distribution Techniques (n.d.). Retrieved from http://bhattbhasker.tripod.com/id8.html (accessed on October 11, 2017).

21. Wallsten, S. (2004). The Role of Government in Regional Technology Development: The Effects of Public Venture Capital and Science Parks. In Bresnahan T. \& Gambardella A. (Eds.). Building High-Tech Clusters: Silicon Valley and Beyond (pp. 229-279). Cambridge: Cambridge University Press.

22. Zhang, X. Q. (2011). The Economic Role of Cities. Nairobi: United Nations Human Settlements Programme, UNHABITAT. 